\title{
Effect of habituation to milking and natural suckling on milking behaviour and milk production characteristics in primiparous Sahiwal cows
}

\author{
Pranay Bharti and Madan Lal Kamboj
}

Received: 03 January 2019 / Accepted: 29 March 2019 / Published online: 22 June 2019

(C) Indian Dairy Association (India) 2019

\begin{abstract}
The present study was performed to investigate the influence of habituation to milking and natural suckling on milking behaviour and milk production characteristics in primiparous Sahiwal cows. For this experiment 18 late pregnant Sahiwal heifers were selected and divided into 3 groups viz. non-habituated to milking routine and weaned, control $(\mathrm{C})$, habituated to milking routine and weaned (T1) and habituated to milking routine and suckled (T2) group. The mean let-down time (C: 91.48, T1: 82.37, $\mathrm{T} 2: 59.85 \mathrm{sec})$, milking temperament score (C: $2.11, \mathrm{~T} 1: 1.83$, T2: $1.33)$ and frequency of defecation $(\mathrm{C}: 0.85, \mathrm{~T} 1: 0.81, \mathrm{~T} 2: 0.62)$ were significantly $(\mathrm{P}<0.05)$ lower in $\mathrm{T} 2$ as compared to $\mathrm{C}$ and $\mathrm{T} 1$ group of cows. The overall means of daily colostrum yield (C: 3.55 , T1: $3.85, \mathrm{~T} 2: 4.68 \mathrm{~kg} /$ day), daily milk yield (C: $4.82, \mathrm{~T} 1: 5.31, \mathrm{~T} 2: 6.84$ $\mathrm{kg} / \mathrm{day})$ and milk flow rate (C: $0.595, \mathrm{~T} 1: 0.623, \mathrm{~T} 2: 0.732 \mathrm{~kg} / \mathrm{min})$ were significantly $(\mathrm{P}<0.05)$ higher in $\mathrm{T} 2$ cows as compared to $\mathrm{C}$ and $\mathrm{T} 1$. The mean plasma cortisol levels after milking were also significantly $(\mathrm{P}<0.05)$ higher in case of $\mathrm{C}$ group cows followed by $\mathrm{T} 1$ and $\mathrm{T} 2$ group of cows. It was concluded that the milking behaviour, milk let-down time and milk production performance were improved while stress level reduced in primiparous Sahiwal cows which were habituated to milking routine and allowed natural calf suckling.
\end{abstract}

Pranay Bharti $(\square)$

LPM, Krishi Vigyan Kendra Dindori, Madhya Pradesh, India

E-mail:dr12pranay@gmail.com

Madan Lal Kamboj

Livestock Production Management Section, ICAR- National Dairy

Research Institute, Karnal 132001 India
Keywords: Habituation, Milk production, Milking behaviour, Suckling, Sahiwal

\section{Introduction}

India is endowed with a large population of indigenous cattle (151 million) which are contributing around 21 per cent of the total milk production in the country. But the average daily milk production of our indigenous cattle is very poor $(2.84 \mathrm{~kg})$ as compared to crossbred and exotic cows $(7.51 \mathrm{~kg})$ as per BAHS, 2017. One of the major reasons of lower milk production of our indigenous cows is shorter milking period in our indigenous cows (Narwariya et al. 2015). Sahiwal is one of the best milch breed among different breeds present in the tropics including India (Rehman et al. 2014) and hence their importance can not be overlooked.

Lactation length is very crucial trait of the milch animal in respect of productivity of the animal. Lactation length in Sahiwal cows was found to be $215.83 \pm 3.08$ days and more than three-fourth (76\%) of total observations failed to reach the standard level of 305 milking days (Narwariya et al. 2015). Death of calves is assumed as a common reason for short lactations as tropical cattle often fail to let-down milk unless stimulated by suckling. In addition, central inhibition of milk ejection in dairy cattle is often associated with emotional stressors, such as practice of milking animal in a novel environment (Bruckmaier et al. 1993) or in case of primiparous heifer, when being introduced to milking for the first time (Van Reenen et al. 2002).

Introducing cattle to new environment can be a potent stressor for cattle (Hopster, 1998). Due to growing herd sizes and increasing economic pressure on dairy farms, the contact between stockpersons and animals often decreases. This leads to more cows and especially heifers that have had only few positive contacts with their stockpersons before parturition, and that show agitation behaviour during milking (Ivemeyer et al. 2015). Previous work has shown that milking cow in unfamiliar surroundings has marked effect on milk yield, milk flow rate and milking duration as animal become stressed under unfamiliar surroundings (Rushen et al. 2001). Whereas, it has been reported that suckling by calf had resulted in improved milk production performance in dairy 
cows and buffaloes in previous studies (Sanh et al. 1997; Kamboj et al. 2011).

Keeping the aforesaid in view present study was planned to study the effect of pre-partum habituation to milking routine and natural suckling on milking behaviour and milk production characteristics in primiparous Sahiwal cows.

\section{Material and method}

\section{Location of the study}

The present study was conducted at the Livestock Research Centre, ICAR-National Dairy Research Institute, Karnal (Haryana). National Dairy Research Institute is located at an altitude of 250 meters above mean sea level, latitude and longitude being $29042 " \mathrm{~N}$ and 77054" E respectively.

\section{Experimental design and animals}

All the animals in the present study were reared under semi intensive system of management at Cattle yard of NDRI, Karnal. The animals were kept under loose housing system with concrete flooring and space in the housing for animals are as per the BIS specifications and animals were managed as per the standard practices followed in the institute's herd. The cows were shifted to the milking herd after 5 days of parturition and maintained under standard feeding and management practices. Eighteen advancedpregnant Sahiwal heifers were randomly selected from Sahiwal herd maintained at the institute and were further divided into three groups.

Control [Non-habituated and weaned (C)]: No habituation to milking routine and weaning of calf from mother at birth and provision of milk ejection stimuli by offering of concentrate mixture at the time of milking.

Habituated and weaned [Treatment-1 ( $\left.T_{p}\right)$ ]: Habituation to milking routine for approximately 21 days before calving and weaning of calf from mother at birth and provision of milk ejection stimuli by offering of concentrate mixture at the time of milking.

Habituated and suckled [Treatment-2 $\left(T_{2}\right)$ ]: Habituation to milking routine for approximately 21 days before calving and provision of milk ejection stimuli by allowing calves to suckle their mother before every milking.

\section{Habituation protocol / regimen followed for milking routine:}

1. Bringing the heifers from paddock in to milking parlour along with other milking cows.

2. Washing and cleaning of pregnant heifers outside the milking parlour.
3. Entering into the flat milking parlour and tying them individually at feed manger.

4. Offering them concentrate mixture.

5. Grooming and massaging of udder and teat area gently for few minutes.

6. The animals were left undisturbed in the milking parlour for about 10-15 min and then taken back to their paddock along with other milking cows.

Parameters recorded during post-partum period of the experiment

Daily colostrum yield (up to 5 days)

Daily yield of colostrum was recorded for individual cows from the day of calving and up to 5 days.

\section{Milk let-down time (seconds)}

The milk let-down time was recorded as the time interval between the provision of milking stimulus (start of udder and teat massage by milker in weaned group and initiation of suckling by calf in suckled group) and full engorgement of teats. The time taken for let-down of milk was recorded using digital stop-watch.

\section{Milking time (min)}

Milking time was recorded as the total time elapsed for the actual milking of animal that is the time from the start of milking to the complete removal of milk. It was recorded by using a digital stopwatch.

\section{Daily milk yield (kg)}

Milk yield for individual cows was recorded as the amount of milk yielded in 24 hours obtained by milking the animals following complete let-down.

\section{Milk flow rate $(\mathrm{kg} / \mathrm{min})$}

The milk flow rate was calculated by dividing the total milk yield (kg) by the milking time. It is calculated by formula given below-

$$
\begin{aligned}
& \text { Milk flow rate }=\quad \text { Total milk yield }(\mathrm{kg}) / \text { Total } \\
& \text { milking time }(\min )
\end{aligned}
$$

\section{Milking temperament (1-5 point scale)}

The milking temperament of experimental cows was observed at weekly interval at the time of milking in milking byre and behaviour was scored according to the five-point scale of milking temperament scores given by Tulloh (1961) which is presented in table 1 .

\section{Plasma cortisol level}


Plasma cortisol was determined to assess the level of stress in cows after morning milking on day 1 st, 7 th and 14 th of milking. The plasma cortisol level was estimated by use of ELISA Kit (Catalog No. CSB-E13064B 96 tests) from CUSABIO.

\section{Statistical analysis}

All the data obtained were categorized according to the objectives of the study and were analysed with the help of statistical software SPSS (version. 17).

The significance of effects of treatments on the different dependent variables was analysed using analysis of variance (ANOVA) procedure and the differences between the means were compared using Tuckey post-hoc test.

\section{Ethical approval}

For the present study, the plan of experiment was approved by Institutional Animal Ethics Committee for animal experiments and the ethical guidelines of the National Dairy Research Institute, Karnal (Haryana) were followed during all the animal experimentations.

\section{Results and discussion}

\section{Daily colostrum yield (kg)}

The overall mean values of daily colostrum yield are presented in Table 2 . The mean values of colostrum yield was significantly $(\mathrm{P}<0.05)$ higher in habituated and suckled cows $\left(\mathrm{T}_{2}\right)$ as compared to non-habituated and weaned $(\mathrm{C})$ and habituated and weaned $\left(\mathrm{T}_{1}\right)$ group of Sahiwal cows. This might be due to proper milk letdown stimulus provided by natural suckling and better let-down of colostrum as suckling by calf is considered as the most post potent stimulus for let-down of milk. Higher average daily colostrum yield in suckled cows as compared to weaned cows has been reported in previous studies (Kumar and Kamboj, 2014; Singh and Kamboj, 2015) which supports the results of present study.

\section{Daily milk yield (kg)}

The overall mean values of daily milk yield are presented in Table 2 . The mean values ofdaily milk yield was significantly $(\mathrm{P}<0.05)$ higher in habituated and suckled $\left(\mathrm{T}_{2}\right)$ group in comparison to non-habituated and weaned (C) and habituated and weaned $\left(\mathrm{T}_{1}\right)$ group. The $\mathrm{T}_{2}$ group of cows produced on an average $41.90 \%$ and $28.81 \%$ higher milk daily than the $\mathrm{C}$ and $\mathrm{T}_{1}$ group of cows respectively, while $\mathrm{T}_{1}$ cows yielded on an average $10.16 \%$ more milk daily than $\mathrm{C}$ group of cows. Although the overall mean daily milk yield of $\mathrm{T}_{1}$ cows was statistically similar to that of $\mathrm{C}$ group, the daily milk yield of $\mathrm{T}_{1}$ group was significantly $(\mathrm{P}<0.05)$ higher than $\mathrm{C}$ group of cows at first week of milking after calving.

This might be due to the effect of suckling by calf because calf suckles the residual milk after milking and enhances production byincreasing the degree of udder emptying (Sandoval-Castro et al. 2000) and higher release of lactogenic hormones i.e. growth hormone and prolactin hormone both during suckling and also after the suckling period (Walch, 1974). In addition to this, calves provides enhanced teat stimulation during suckling (Bar-Peled et al. 1995) and more development of the milk secreting cell in the mammary gland of suckled cows due to frequent emptying of udder (Hale et al. 2003) which results into more milk production.

The results obtained in the present study are in agreement with the findings of previous reports where significantly higher milk yields in purebred exotic cows (Mejia et al. 1998), crossbred cows (Boonbrahm et al. 2004a), Tharparkar cows (Upadhyay et al. 2015) and Murrah buffaloes (Kumar et al. 2017; Singh et al. 2017) were reported when cows were allowed restricted suckling by their calves. However, various studies on the effect of pre-partum

Table 1 Milking temperament score chart as given by Tulloh (1961)

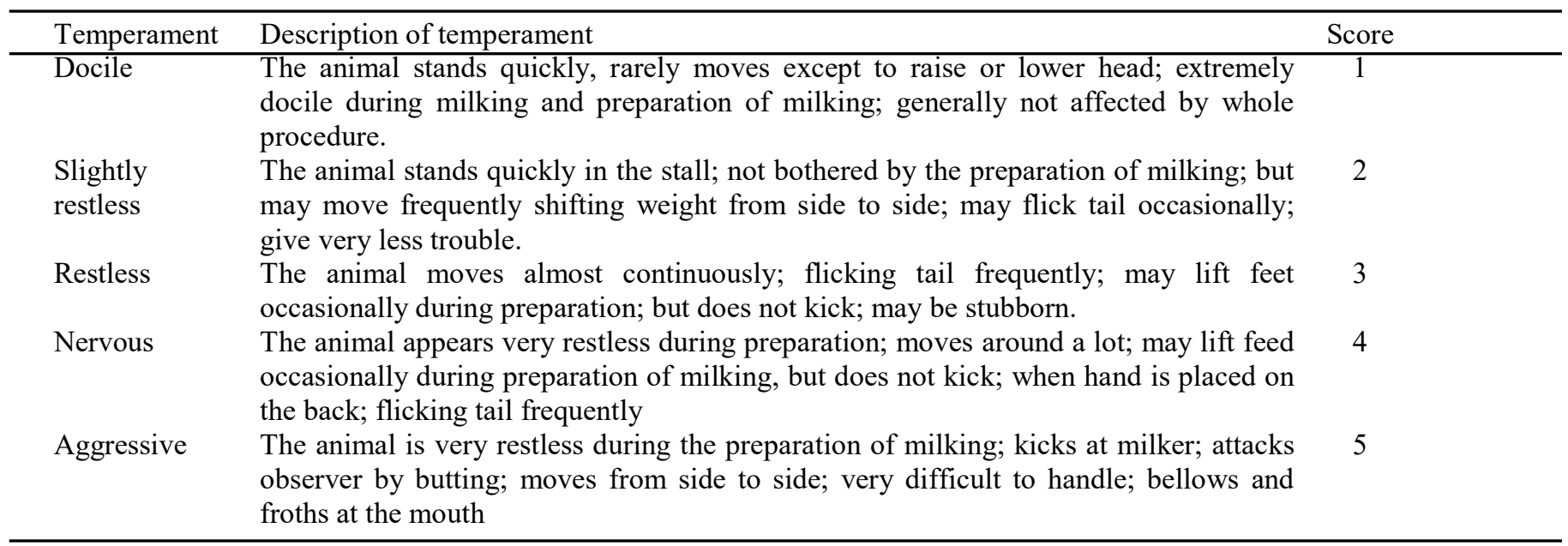


training or habituation to milking routine has shown no significant difference between overall mean milk yield of trained and untrained cows (Bertenshaw et al. 2008; Dowling and Sutherland, 2012; Ivemeyer et al. 2015).

\section{Milking time (min)}

The overall mean values of milking time are presented in Table 2. The mean values of mean milking time was significantly higher $(\mathrm{P}<0.05)$ in habituated and suckled $\left(\mathrm{T}_{2}\right)$ group than that of nonhabituated and weaned $(\mathrm{C})$, habituated and weaned $\left(\mathrm{T}_{1}\right)$ group, while milking time between $\mathrm{C}$ and $\mathrm{T}_{1}$ group did not differ significantly.

The higher milking time in $\mathrm{T}_{2}$ group of cows might be due to higher milk yield in these cows. Similar to present findings, Upadhyay et al. $(2015)$ reported significant $(\mathrm{P}<0.01)$ effect of suckling on milking time in Tharparkar cows. The findings of the present study also supported by the results of previous experiments in which non-significant effect of habituation to milking routine on milking time in primiparous Friesian cows (Dowling and Sutherland, 2012) and in primiparous buffaloes (Polikarpus et al. 2014) have been reported.

\section{Milk flow rate (Kg/min)}

The overall mean values of milk flow rate are presented in Table 2 . The mean values of milk flow rate was significantly higher $(\mathrm{P}<0.05)$ in habituated and suckled $\left(\mathrm{T}_{2}\right)$ group in comparison to non-habituated and weaned $(\mathrm{C})$, habituated and weaned $\left(\mathrm{T}_{1}\right)$ group. However, the mean milk flow rate of $\mathrm{C}$ group and $\mathrm{T}_{1}$ group were statistically almost similar.

The higher milk flow rate in $\mathrm{T}_{2}$ group of cows may have been caused by thesuckling by their calves resulting in complete letdown of milk as strong stimulus of calf possibly accounted for the strong milk ejection leading to rapid evacuation of udder. In addition to this, better temperament in $\mathrm{T}_{2}$ cows as compared to other groups of cows might have led to calm and quite milking. Similarly, higher mean milk flow rate in suckled as compared to weaned group of cows (Upadhyay et al. 2015) and Murrah buffaloes (Singh et al. 2017; Kumar and Kamboj, 2014) have been reported.

\section{Milking temperament}

The overall mean values of milking temperament score are presented in Table 2. The mean values of milking temperament score was significantly $(\mathrm{P}<0.05)$ lower in habituated and suckled $\left(\mathrm{T}_{2}\right)$ group followed by habituated and weaned $\left(\mathrm{T}_{1}\right)$ andnonhabituated and weaned $(\mathrm{C})$ cows. The lower milking temperament score of $\mathrm{T}_{1}$ than $\mathrm{C}$ group of cows indicated that habituation to milking routine prior calving was effective in earlier adaptation to milking routine in $\mathrm{T}_{1}$ cows. Further, the lower mean milking temperament scores observed in the $\mathrm{T}_{2}$ as compared to $\mathrm{C}$ and $\mathrm{T}_{1}$ group of cows may be attributed to cumulative effect of prepartum habituation and the presence of the calf during milking and the maternal bonding of the cows with the calf due to which probably there was no stress of weaning in $\mathrm{T}_{2}$ cows. The results on the effect of habituation on milking temperament in this experiment are in line with the findings of Das and Das (2004) in cows and of Viswakarma and Kamboj (2005) in buffaloes. The

Table-2 Mean \pm SE of various parameters for different group of primiparous Sahiwal cows

\begin{tabular}{lllc}
\hline Parameters & $\begin{array}{l}\text { Non-habituated and } \\
\text { weaned }(\mathrm{C})\end{array}$ & $\begin{array}{l}\text { Habituated and weaned } \\
\left(\mathrm{T}_{1}\right)\end{array}$ & $\begin{array}{c}\text { Habituated and suckled } \\
\left(\mathrm{T}_{2}\right)\end{array}$ \\
\hline Colostrum yield (kg/day) & $3.55^{\mathrm{A}} \pm 0.12$ & $3.85^{\mathrm{A}} \pm 0.11$ & $4.68^{\mathrm{B}} \pm 0.16$ \\
Milk yield (kg/day) & $4.82^{\mathrm{A}} \pm 0.14$ & $5.31^{\mathrm{A}} \pm 0.20$ & $6.84^{\mathrm{B}} \pm 0.13$ \\
Milking time (min) & $8.35^{\mathrm{A}} \pm 0.25$ & $8.51^{\mathrm{A}} \pm 0.28$ & $9.36^{\mathrm{B}} \pm 0.16$ \\
Milk flow rate (Kg/min) & $0.595^{\mathrm{A}} \pm 0.012$ & $0.623^{\mathrm{A}} \pm 0.008$ & $0.732^{\mathrm{B}} \pm 0.009$ \\
Milking temperament score & $2.11^{\mathrm{A}} \pm 0.06$ & $1.83^{\mathrm{B}} \pm 0.04$ & $1.33^{\mathrm{C}} \pm 0.03$ \\
(1-5 point scale) & & & $59.85^{\mathrm{C}} \pm 1.02$ \\
Milk let down time (seconds) & $91.48^{\mathrm{A}} \pm 1.09$ & $82.37^{\mathrm{B}} \pm 0.88$ & \\
\hline
\end{tabular}

Means bearing different superscripts differ significantly $(\mathrm{P}<0.05)$

Table 3 Mean ( \pm SE) of plasma cortisol levels $(\mathrm{ng} / \mathrm{ml})$ after milking in three different groups of Sahiwal cows

\begin{tabular}{lllc}
\hline $\begin{array}{l}\text { Day of } \\
\text { milking }\end{array}$ & $\begin{array}{l}\text { Non-habituated and } \\
\text { weaned }(\mathrm{C})\end{array}$ & $\begin{array}{l}\text { Habituated and } \\
\text { weaned }\left(\mathrm{T}_{1}\right)\end{array}$ & $\begin{array}{c}\text { Habituated and } \\
\text { suckled }\left(\mathrm{T}_{2}\right)\end{array}$ \\
\hline 1 & $17.85^{\mathrm{A}} \pm 0.35$ & $14.79^{\mathrm{B}} \pm 0.58$ & $10.32^{\mathrm{C}} \pm 0.49$ \\
7 & $12.60^{\mathrm{A}} \pm 0.49$ & $10.43^{\mathrm{B}} \pm 0.46$ & $7.21^{\mathrm{C}} \pm 0.36$ \\
14 & $8.39 \pm^{\mathrm{A}} 0.44$ & $7.57^{\mathrm{A}} \pm 0.31$ & $5.90^{\mathrm{B}} \pm 0.52$ \\
\hline
\end{tabular}

Means bearing different superscripts across row differ significantly $(\mathrm{P}<0.05)$ 
findings of the present study are further corroborated by the results obtainedinpreviousinvestigations where significantly $(\mathrm{P}<0.05)$ lower milking temperament score in suckled groupas compared to weaned group of Murrah buffaloes (Kumar and Kamboj, 2014; Singh et al. 2017) has been reported.

\section{Milk let-down time (seconds)}

The overall mean values of milk let-down time are presented in Table 2. The mean values of mean milk let-down time was significantly $(\mathrm{P}<0.05)$ lower in habituated and suckled $\left(\mathrm{T}_{2}\right)$ group and habituated and weaned $\left(\mathrm{T}_{1}\right)$ group than that of nonhabituated and weaned (C) group. The results of present study indicated that pre-partum habituation to milking reducedmean let-down time of $\mathrm{T}_{1}$ group was significantly $(\mathrm{P}<0.05)$ lower than $\mathrm{C}$ group of cows and milk let-down time of $\mathrm{T}_{2}$ group was significantly $(\mathrm{P}<0.05)$ lower than $\mathrm{C}$ and $\mathrm{T}_{1}$ group of cows which indicated that the practices of pre-partum habituation to milking along with natural suckling by calf had caused reduction in time for letdown of milk. Significantly high milk let-down time in control group cows may be attributed to stress and being more apprehensive which might have adversely affected the release of hormones responsible for milk let-down and emptying of udder in these cows. The stronger effect of the suckling by calf as stimulus on oxytocin release has been well documented (Samuelsson and Svennersten, 1996; Tancin et al. 1994).

The results on the effect of habituation in this experiment are in agreement with the findings of Das and Das (2004) who revealed that the pre-partum udder massaging enabled quick milk let down along with reduction in the level of fear in primiparous cows. The findings in the present study are further corroborated by the results of Upadhyay et al. (2015) in Tharparkar cows and by the results of Singh et al. (2017) and Kumar and Kamboj (2014) in Murrah buffaloes.

\section{Plasma cortisol levels}

The mean cortisol concentrations showed a continuous declining trend with the advancement of lactation in all the three groups of cows (Table 3 ). On $1^{\text {st }}$ and $7^{\text {th }}$ day of milking the mean plasma cortisol level were significantly $(\mathrm{P}<0.05)$ higher in non-habituated and weaned $(\mathrm{C})$ cows followed by habituated and weaned $\left(\mathrm{T}_{1}\right)$ and habituated and suckled $\left(\mathrm{T}_{2}\right)$ groups of cows.

The higher level of cortisol concentration in non-habituated and weaned cows indicated that these animals were under high level of stress when exposed to unfamiliar surroundings of milking routine and when milking was performed without the presence of their calves. It has been found that there is ahigh release of oxytocin in cow during suckling (Lupoli et al. 2001) which may exerts anti-stress like effects (Petersson et al. 1996) and decreased cortisol levels (Petersson et al. 1999).
In previous reports also higher concentration of cortisol in cows under unfamiliar surroundings which decreased gradually with the increased number of exposure to unfamiliar surroundings (Bruckmaier et al. 1996; Vishwakarma and Kamboj, 2005). These results are also on similar lines with previous studies which reported that the artificial rearing induced significantly $(\mathrm{P}<0.05)$ higher level of serum cortisol concentration in cows than did in restricted suckling (Singh et al. 2017; Kumar and Kamboj, 2014; Hernandez et al. 2006).

\section{Conclusions}

The results of present study revealed that the milking behaviour and milk production performance were improved while milk letdown time and stress level reduced in primiparous Sahiwal cows which were habituated to milking routine and allowed natural calf suckling. The primiparous Sahiwal cows habituated to milking routine and weaned had better milking temperament and milk letdown time and reduced stress level as compared to nonhabituated and weaned cows.

\section{Acknowledgements}

The authors are highly thankful to the Director of ICAR-NDRI Karnal, for providing the necessary facilities to carry out the research and also extend our gratitude for financial assistant in terms of institutional fellowship to first author during entire tenure.

\section{References}

Bar-Peled U, Maltz E, Bruckental I, Folman Y, Kali Y, Gacitua H, Lehrer AR, Knight CH, Robinzon B, Voet $\mathrm{H}$ and Tagari H (1995) Relationship between frequent milking or suckling in early lactation and milk production of high producing dairy cows. J Dairy Sci 78: 2726-2736

BAHS (2017) Basic Animal Husbandry and Fisheries Statistics. Government of India Ministry of Agriculture, Department of Animal Husbandry, Dairying and Fisheries, Krishi Bhawan, New Delhi

Bertenshaw C, Rowlinson P, Edge H, Douglas S, Shiel R (2008) The effect of different degrees of 'positive' human-animal interaction during rearing on the welfare and subsequent. Appl Anim Behav Sci 114 (1): $65-75$

Boonbrahm N, Peters KJ, Intisang W (2004a). The influence of calf rearing methods and milking methods on performance traits of crossbred dairy cattle in Thailand. 1. Milk yield and udder health. Arch Tierz, Dummerstorf 47(3): 211-224

Bruckmaier R M, Schams D, JW Blum (1993) Milk removal in familiar and unfamiliar surroundings: Concentrations of oxytocin, prolactin, cortisol and â-endorphin. J Dairy Res 60: 449-456

Bruckmaier RM, Pfeilsticker HU, JW Blum (1996) Milk yield, oxytocin and â-endorphin gradually normalized during repeated milking in unfamiliar surroundings. J Dairy Res 63:191- 200

Das KS, Das N (2004) Pre-partum udder massaging as a means for reduction of fear in primiparous cows at milking. Appl Anim Behav Sci 89(1): $17-26$

Dowling SK, Sutherland MA (2012) The effect of training to the milking parlour on the behavioural response to milking and milk production 
in first lactation heifers. Proceedings of the New Zealand Society of Animal Production 72: 134-138

Hale SA, Capuco, AV, Erdman RA (2003) Milk yield and mammary growth effects due to increased milking frequency during early lactation. J Dairy Res 6: 2061-2071

Hernandez C, Orihuela A, Froberg S, Lidfors LM (2006) Effect of restricted suckling on physiological and behavioural stress parameters in dualpurpose cattle in the tropics. Livest Sci 99: 21- 27

Hopster H, Van Der Werft JTN, Blokhuis HJ (1998) Side preference of dairy cows in the milking parlour and its effects on behaviour and heart rate during milking. Appl Anim Behav Sci 55: 213-229

Ivemeyer S, Pisani M and Knierim U (2015) Short-term ante-calving handling of dairy heifers in relation to heifers' behaviour and udder health after parturition. Appl. Anim. Behav. Sci 171: 33-38

Kamboj M L, Shiv Prasad, Harika AS, Dutt C and Kumar N (2011) Development of organic milk production system, Annual Report (2010-2011), National Dairy Research Institute, Karnal (Haryana). PP: $14-15$

Kumar A, Kamboj ML, Kumar S, Jingar SC, Lawania P and Bugaliya HL (2017) Performance of Murrah Buffalo and their Calves under Weaning and Suckling System. Int J Curr Microbiol App Sci 6(7): 2452-2459

Kumar A, Kamboj ML (2014) Influence of weaning on the performance and behaviour of calves and their dams in Murrah buffaloes. $\mathrm{PhD}$ Thesis Submitted to ICAR-NDRI, Deemed University Karnal

Lupoli B, Johansson B, Uvn"as-Moberg K, Svennersten-Sjaunja K (2001) Effect of suckling on the release of oxytocin, prolactin, cortisol, gastrin, cholecystokinin, somatostatin and insulin in dairy cows and their calves. J Dairy Res 68: 175-187

Mejia CE, Preston TR, Fajersson P (1998) Effects of restricted suckling versus artificial rearing on milk production, calf performance and reproductive efficiency of dual purpose Mpwapwa cattle in a semiarid climate. Livest Res Develop 10 (1)

Narwariya US, Mehla RK, Verma KK, Lathwal SS, Yadav R, Verma AK (2015) Study of short lactation in Sahiwal cattle at organized farm. Vet World 8 (5): 690-694

Petersson M, Alster P, Lundeberg T and Uvnas-Moberg K (1996) Oxytocin causes a long term decrease of blood pressure in female and male rats. Physiol Behav 60(5): 1311-1315

Petersson M, Hulting AL, Uvnas-Moberg K (1999) Oxytocin causes a sustained decrease in plasma levels of cortisosterone in rats. Neurosci Lett 266: 41-44

Polikarpus A, Napolitano F, Grasso F, Palo RD, Zicarelli F, Arney D and Rosa GD (2014) Effect of pre-partum habituation to milking routine on behaviour and lactation performance of buffalo heifers. Appl Anim Behav Sci 161: 1-6

Rehman H, Khan MS, Mirza A (2014) Factors affecting performance of Sahiwal cattle - A review. J Anim Plant Sci 24(1): 1-12

Rushen J, Munksgaard L, Marnet PG, DePassillé AM (2001) Human contact and the effects of acute stress on cows at milking. Appl Anim Behav Sci 73: 1-14

Samuelsson B, Svennersten K (1996) Effect of suckling on the release of oxytocin in dairy cows and their calves. In: Proceedings of the Symposium on Milk Synthesis, Secretion, and Removal in Ruminants, Bern, 26-27April 1996, pp. 75

Sandoval-Castro CA, Anderson S, Leaver JD (2000) Production responses of tropical crossbred cattle to supplementary feeding and to different milking and restricted suckling regimes. Livest Prod Sci 66: 13-23

Sanh MV, Preston T R, LeViet L (1997) Effects of restricted suckling versus artificial rearing on performance and fertility of crossbreed F1 (Holstein Friesian $\times$ Local) cows and calves in Vietnam. Livest Res Rural Develop 9: 4

Singh, PK, Kamboj ML, Chandra S , Singh RK (2017) Effect of calf suckling dummy calf used and weaning on milk ejection stimuli and milk yield of Murrah buffaloes (Bubalus bubalis). J Pharmacognosy Phytochem 1: 1012-1015

Singh P K, Kamboj ML (2015) Effect of various milk letdown stimuli on the performance and behaviour of Murrah buffaloes and their calves. PhD Thesis, ICAR-NDRI, Deemed University Karnal.

Tancin V, Broucek J, Harcek L, Uhrincat M, Mihina S, Cupka P (1994) Suckling and machine milking-influenced secretion of oxytocin, cortisol and milk characteristic in primiparous dairy cows. In: Proceedings of the 3rd International Housing Conference on Dairy System for the $21^{\text {st }}$ Century, ASAE, Orlando, FL, 2-5 February 1994 , pp. $426-433$

Upadhyay VK, Tomar AKS, Patel BHM, Golher DM, Sahu S, Bharti PK (2015) Effect of early weaning on milking behaviour, production and reproduction of Tharparkar cows. Indian J Dairy Sci 68(5):477482

VanReenen CG, VanderWerf JTN, Bruckmaier RM, Hopster H, Engel B, Noordhuizen JPTM, Blokhuis HJ (2002). Individual differences in behavioraland physiological responsiveness of primiparous dairy cows to machine milking. J Dairy Sci 85 : 2551-2561

Viswakarma VK, Kamboj ML (2005) Influence of pre-partum training on post-partum milking behaviour and production performance of dairy heifers. M.V.Sc. Thesis, Deemed University, NDRI, Karnal

Walch JP (1974) Milk secretion in machine milked and suckled cows. Irish J Agr Food Res 13: 77-89 